\title{
From transcriptome to biological function: environmental stress in an ectothermic vertebrate, the coral reef fish Pomacentrus moluccensis
}

\author{
Karin S Kassahn*1,5, Ross H Crozier ${ }^{1}$, Alister C Ward ${ }^{2}$, Glenn Stone ${ }^{3}$ and \\ M Julian Caley ${ }^{4}$
}

Address: ${ }^{1}$ School of Marine and Tropical Biology, James Cook University, Townsville, QLD 4811, Australia, ${ }^{2}$ School of Medicine, Deakin University, Geelong, VIC 3217, Australia, ${ }^{3}$ CSIRO Mathematical and Information Sciences, North Ryde, NSW 2113, Australia, ${ }^{4}$ Australian Institute of Marine Sciences, PMB No.3, Townsville, QLD 4810, Australia and ${ }^{5}$ ARC Centre of Excellence in Bioinformatics and Institute for Molecular Bioscience, The University of Queensland, Brisbane, QLD 4072, Australia

Email: Karin S Kassahn* - k.kassahn@imb.uq.edu.au; Ross H Crozier - ross.crozier@jcu.edu.au; Alister C Ward - alister.ward@deakin.edu.au; Glenn Stone - glenn.stone@csiro.au; M Julian Caley - j.caley@aims.gov.au

* Corresponding author

Published: 5 October 2007

BMC Genomics 2007, 8:358 doi:10.1/86/147|-2164-8-358

This article is available from: http://www.biomedcentral.com/I47I-2/64/8/358

(c) 2007 Kassahn et al; licensee BioMed Central Ltd.

This is an Open Access article distributed under the terms of the Creative Commons Attribution License (http://creativecommons.org/licenses/by/2.0), which permits unrestricted use, distribution, and reproduction in any medium, provided the original work is properly cited.

\begin{abstract}
Background: Our understanding of the importance of transcriptional regulation for biological function is continuously improving. We still know, however, comparatively little about how environmentally induced stress affects gene expression in vertebrates, and the consistency of transcriptional stress responses to different types of environmental stress. In this study, we used a multi-stressor approach to identify components of a common stress response as well as components unique to different types of environmental stress. We exposed individuals of the coral reef fish Pomacentrus moluccensis to hypoxic, hyposmotic, cold and heat shock and measured the responses of approximately 16,000 genes in liver. We also compared winter and summer responses to heat shock to examine the capacity for such responses to vary with acclimation to different ambient temperatures.

Results: We identified a series of gene functions that were involved in all stress responses examined here, suggesting some common effects of stress on biological function. These common responses were achieved by the regulation of largely independent sets of genes; the responses of individual genes varied greatly across different stress types. In response to heat exposure over five days, a total of 324 gene loci were differentially expressed. Many heat-responsive genes had functions associated with protein turnover, metabolism, and the response to oxidative stress. We were also able to identify groups of co-regulated genes, the genes within which shared similar functions.

Conclusion: This is the first environmental genomic study to measure gene regulation in response to different environmental stressors in a natural population of a warm-adapted ectothermic vertebrate. We have shown that different types of environmental stress induce expression changes in genes with similar gene functions, but that the responses of individual genes vary between stress types. The functions of heatresponsive genes suggest that prolonged heat exposure leads to oxidative stress and protein damage, a challenge of the immune system, and the re-allocation of energy sources. This study hence offers insight into the effects of environmental stress on biological function and sheds light on the expected sensitivity of coral reef fishes to elevated temperatures in the future.
\end{abstract}




\section{Background}

Microarray technology provides a powerful tool for investigating gene regulation and its significance for biological function. However, our understanding of such relationships during environmental stress remains fragmentary, especially in vertebrates. In particular, the commonality, or otherwise, of the responses of vertebrates to different environmental stresses remain poorly understood. Recently, some understanding of responses to individual stresses, in particular those related to thermal stress in teleost fishes, has been gained. In these species, thermal stress can lead to changes in ventilation and circulation rates [1], changes in mitochondrial densities and their properties [2,3], and a reduction in cellular oxygen levels $[4,5]$. Reduced cellular oxygen levels can lead to increased levels of oxidative stress and hence, the cellular response to thermal stress often includes responses aimed at alleviating oxidative stress $[2,6]$. For example, antioxidant enzymes, such as superoxide dismutase, catalase, and glutathione peroxidase are commonly activated during thermal stress $[7,8]$. Oxidative stress, and the cellular damage associated with it, can in turn induce a heat shock response primarily aimed at the molecular repair of protein damage [9-12]. In addition, thermal stress can lead to extensive changes in gene expression [13-16]. These transcriptional responses are likely the result of the stressdependent activation of only a limited number of upstream regulators, namely the activation mitogen-activated protein kinases (MAPK), in particular the JNK and p38 signalling pathways [17-19], and immediate early genes $[20,21]$. These complex transcriptional responses to stress necessarily precede adjustments at the protein level, and thus, are expected to form an important component of the cellular response to stress.

To advance our current limited understanding of the consistency of transcriptional stress responses across different environmental stress types, it is necessary to examine stress responses to a diversity of stressors simultaneously and a suitable model organism is required. Teleost fishes, and coral reef fishes in particular, are one such potential model. Being ectothermic and aquatic and because their physiology is tightly linked to the environment, teleost fishes are particularly amenable to experimental manipulation of environmental stresses and have hence become important models for environmental stress studies [1316]. Coral reef fishes inhabit relatively stable environments compared to those experienced by many other teleost fishes, and are so likely to have increased sensitivity towards thermal and environmental anomalies. By identifying the most sensitive biological processes in organisms with limited tolerance towards environmental anomalies, we gain understanding of the types of processes that must have been the targets of adaptation in organisms that exhibit broad environmental tolerances [see $[2,22]$ for examples]. In this way, studying environmental stress responses in coral reef fishes may provide fundamental insights into mechanisms of environmental adaptation.

While there are currently no species-specific microarrays available for any species of coral reef fish, we have previously shown that the Compugen $16 \mathrm{~K}$ oligonucleotide microarray developed for the zebrafish, Danio rerio, can be successfully used to study gene responses in the coral reef fish Pomacentrus moluccensis [23]. In this previous study, comparative genomic hybridisation experiments showed good cross-hybridisation between the two fish species for most genes represented on the microarray, and differential expression of a set of candidate genes were confirmed by quantitative real-time PCR [23]. Here, we use this previously validated heterologous microarray approach to measure transcriptional responses of the coral reef fish Pomacentrus moluccensis to different environmental stressors, including hypoxia, hyposmotic stress, cold, and heat. We also compare heat stress responses of winter- and summer-acclimated fish to estimate seasonal effects on gene regulation. The duration of environmental stress treatments was varied, permitting different aspects of the biological response to be examined. Short-term exposure experiments over three hours investigated early gene responses and upstream regulators of transcriptional stress responses, while prolonged exposure to heat over five days investigated medium-term effects of heat stress. By grouping genes into functional categories and identifying those functional categories most commonly associated with gene responses to different types of environmental stress, we identify components of a common stress response in $P$. moluccensis as well as features unique to different types of environmental stress. We use these gene function responses to infer stress-induced changes in biological and physiological function and discuss the types of biological functions affected by exposure to environmental stress.

\section{Results}

\section{Early gene responses to different environmental stresses}

To characterise environmental stress responses, we analysed the gene expression profiles of 118 individuals. These individuals were from a natural population of $P$. moluccensis and were either subjected to one of the environmental stress treatments or kept at ambient conditions. The microarray platform, data series, and raw data including the tif image and spot files are available from the Gene Expression Omnibus website [24] under accessions GPL3365, GSE7499, and GSM181765GSM181823. Most genes that showed significant expression changes in response to short-term cold, heat, hypoxic or hyposmotic shock were down-regulated compared to the expression levels measured in fish kept at ambient conditions (Figure 1, see Additional File 1 for a complete 

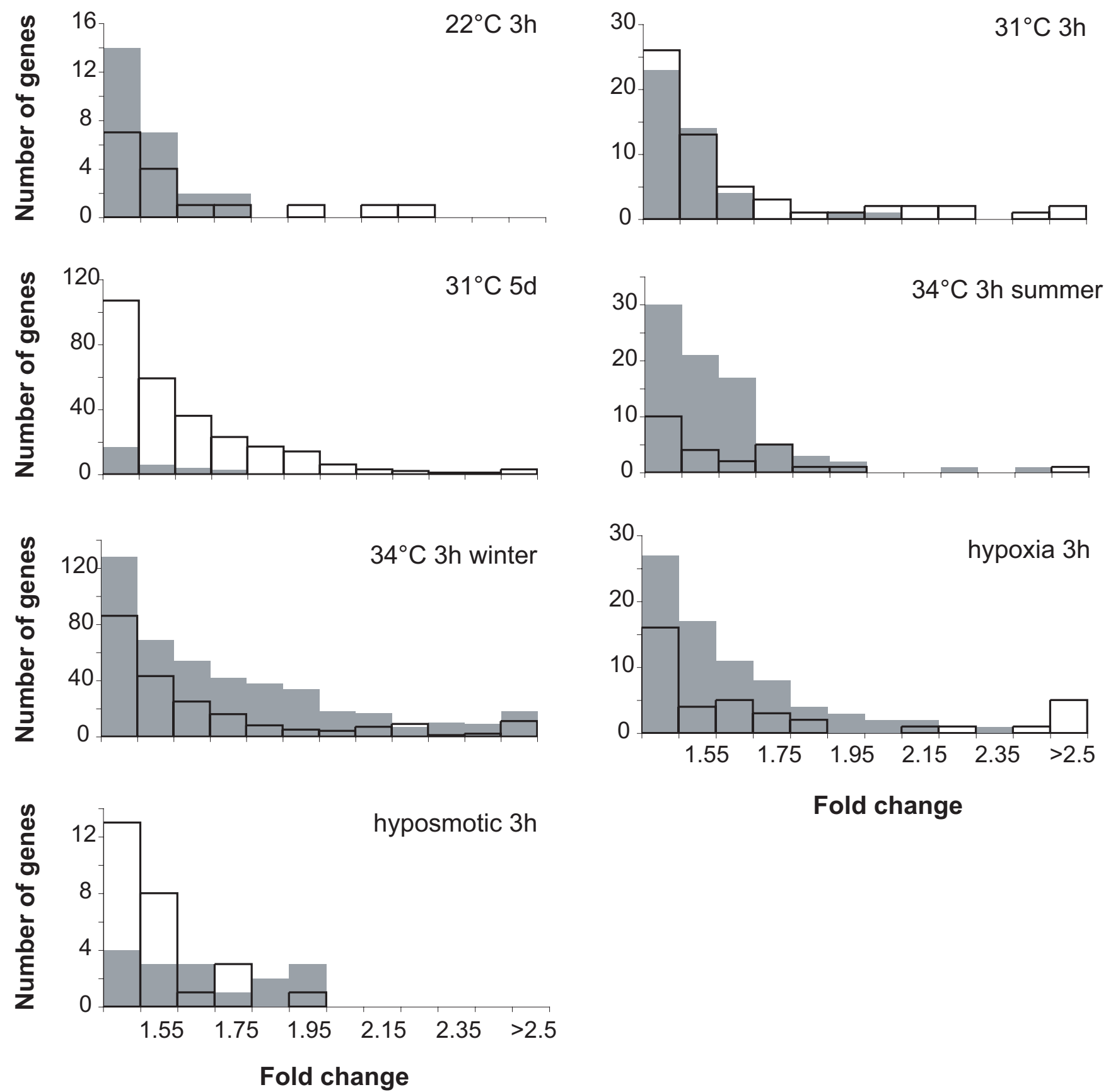

Fold change

Figure I

Summary of gene expression fold changes of Pomacentrus moluccensis in response to environmental stresses. Grey boxes indicate down-regulation, white boxes indicate up-regulation of gene in stressed fish relative to fish kept at ambient conditions.

list of gene responses). Short-term heat shock at $34^{\circ} \mathrm{C}$ in summer led to significant expression changes at six gene loci, amongst which were pdip5, rhoA, and ZCCHC11, and three genes showed greater than two-fold expression changes (Additional File 1). In contrast to the summer response, the short-term $34^{\circ} \mathrm{C}$ heat shock response in winter involved many more genes, and the observed expression changes generally were of greater magnitude (Figure 1, see also [23]). In total, 111 gene loci were differentially expressed in the winter-response to short-term heat shock at $34^{\circ} \mathrm{C}$. All but six of these genes were downregulated in heat-stressed fish with fold changes up to 3.8. 
The early transcriptional response to hypoxia involved ten differentially expressed genes, amongst which were acin $1 a, \beta$-actin, $l b r$, and ela2, and a total of thirteen genes with greater than two-fold expression changes (Additional File 1). Hyposmotic shock resulted in no significant expression changes, and none of the genes assayed showed greater than two-fold expression changes. It is possible that other tissues, for example gills, might have shown a greater response to hyposmotic challenge, but measurement of expression changes in multiple tissues was outside the scope of this study. Due to this lack of response in liver tissue, hyposmotic stress is not discussed further.

\section{Gene regulation in response to prolonged heat}

Prolonged exposure to $31^{\circ} \mathrm{C}$ over five days resulted in 324 differentially expressed genes, most of which - in contrast to the short-term exposure experiments - were induced and 15 of which showed greater than two-fold expression changes (Figure 1, see Additional File 2 for a complete list of gene responses). Genes encoding protein kinase $\mathrm{C}$ substrate $80 \mathrm{~K}-\mathrm{H}$, rab escort protein 1 , semaphorin $3 \mathrm{ab}$, distalless homeobox 3, and TTF-I interacting peptide 5 showed the greatest regulation (Additional File 2). Differentially expressed genes belonged to a variety of gene functions, amongst which were protein processing, signal transduction, and transcription and translation. Only four percent had been previously associated with the response to stress, while 47 percent were of yet unknown gene function (Figure 2).

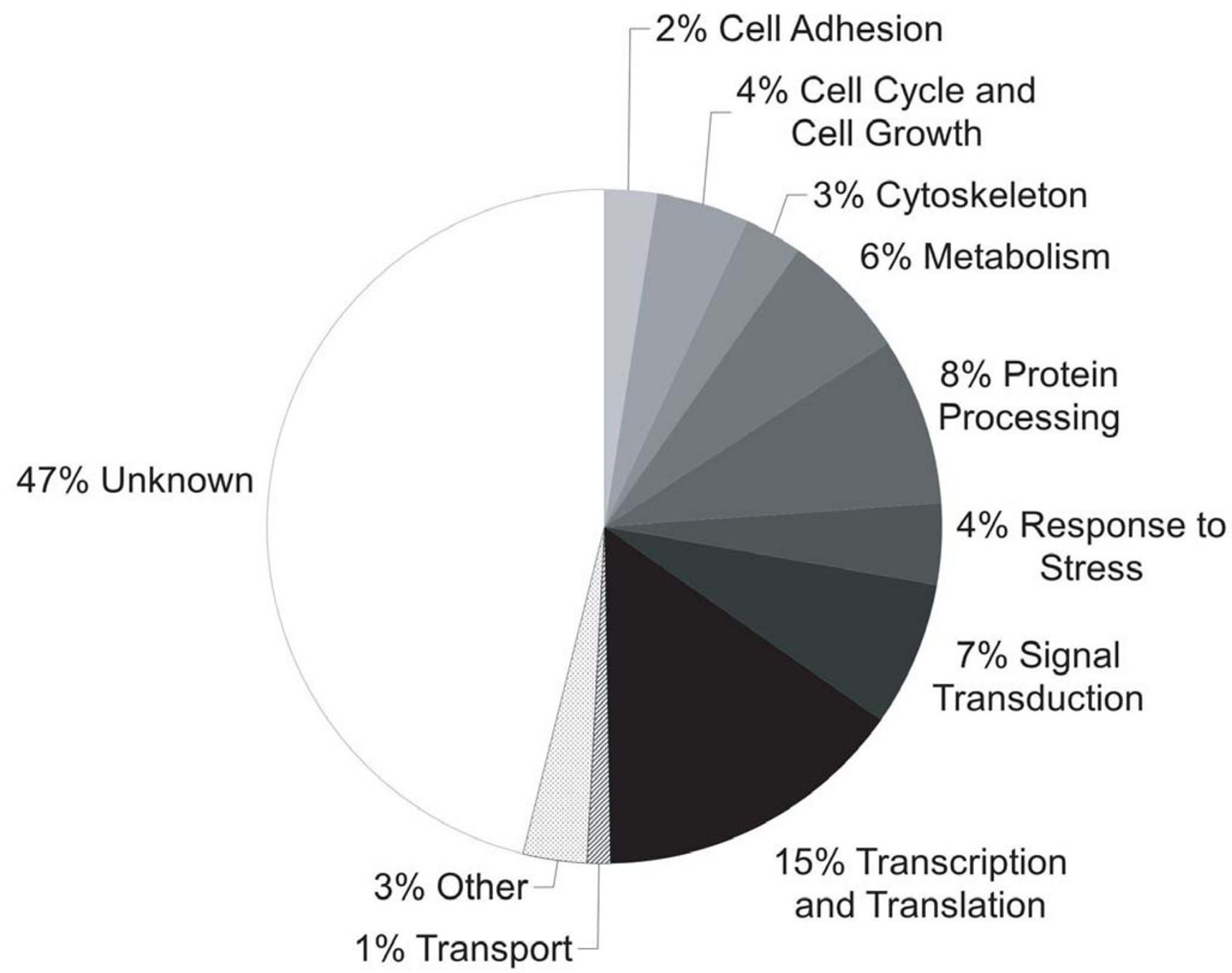

Figure 2

Gene function categories associated with prolonged heat exposure. Gene function categories summarise the gene expression response of Pomacentrus moluccensis to heat exposure at $31^{\circ} \mathrm{C}$ over five days. 


\section{Common effects of stress on biological function}

The gene expression responses to different environmental stressors can be tested for the presence of common gene function responses. Such an approach can aid the interpretation of gene regulation in terms of the types of biological functions that are affected. We thus grouped individual genes on the basis of their gene function. We then tested whether genes of a certain function were more likely to be differentially expressed in response to environmental stress than expected if differential expression was independent of gene function. Such gene set analysis revealed significant association of a number of gene functional groups with the gene responses to different types of environmental stress (Table 1). In particular, gene functions related to cell growth and cytoskeleton, protein turnover, and metabolism were consistently associated with gene responses to environmental stress, regardless of the type of stressor applied (Table 1).

\section{Variable gene responses across stress treatments}

Having identified common gene function responses, we wanted to visualise the responses of individual genes across stress treatments and test for the presence of a set of commonly induced, or suppressed, genes. For this purpose, we extracted the expression data from all differentially expressed genes across all treatments and organised the expression profiles using unsupervised hierarchical clustering. Hierarchical clustering identified four main clusters, with genes belonging to the same cluster showing coordinated responses across stressors (Figure 3). While we identified groups of co-regulated genes, gene responses varied considerably across stressors. Individual genes that showed differential expression in one treatment did not necessarily show a significant response in another treatment, and some genes showed expression changes in opposite directions in response to different stressors (Figure 3). Cluster I was comprised of genes which were strongly induced in the $31^{\circ} \mathrm{C}$ five days treatment, but showed variable responses in the short-term treatments. A subset of cluster I genes was generally down-regulated in the short-term treatments (group a, Figure 3). In order to determine whether there was a relationship between cluster identity and gene function, i.e. whether co-regulated genes shared similar gene functions, we performed gene class testing on the clusters identified by hierarchical clustering using over-representation analysis. The gene ontology 'MHC class I protein binding' was significantly over-represented amongst cluster I genes (Table 2). Cluster II contained a series of genes that were strongly downregulated in the $34^{\circ} \mathrm{C}$ winter treatment and which showed variable expression responses in the other treatments. A subset of cluster II genes was down-regulated in most stress treatments examined (group b, Figure 3). Cluster II genes showed significant over-representation of gene functions related to cell growth and cytoskeleton
(Table 2). Cluster III was comprised of genes that were strongly suppressed during prolonged heat at $31^{\circ} \mathrm{C}$ and most of which were induced in the short-term treatments, especially group c genes (Figure 3). Metabolic gene functions were significantly over-represented amongst cluster III genes (Table 2). Lastly, cluster IV included genes that were strongly induced in the $31^{\circ} \mathrm{C}$ five days treatment and which were generally also induced in the short-term treatments, especially genes in group d (Figure 3). Stressrelated gene functions showed a trend for over-representation amongst cluster IV genes, but just exceeded the threshold for significance after FDR-correction (Table 2).

\section{Discussion}

This is the first study to examine the effects of different types and durations of environmental stress on transcriptional regulation in an ectothermic vertebrate, in this case the coral reef fish $P$. moluccensis. We identified a series of gene functions that were consistently associated with gene responses to environmental stress, suggesting common effects of different types of stress on biological function. However, these common responses were achieved by the regulation of largely independent sets of genes. Thus, there was conservation of gene function responses, but variability in the responses of individual genes. While the expression response of individual genes varied depending on the types and durations of stresses applied, we have identified groups of co-regulated genes, the genes within which shared similar gene functions.

\section{Common gene function responses elucidate how stress affects P. moluccensis}

Some gene functions were consistently associated with the stresses applied here, and thus are likely to reflect the common effects of environmental stress on biological function in this species. Consistent with the observation that stress negatively affects cell growth $[25,26]$ and that, therefore, actin cytoskeletal elements are commonly regulated in response to stress $[27,28]$, the gene ontologies 'actin cytoskeleton organization and biogenesis', 'anti-apoptosis', 'induction of apoptosis', and 'cell cycle' were associated with most stress responses measured here. Individual stress-responsive genes in this category included $\beta$-actin, plectin 1, dynein, spectrin, tubulin beta-2, filamin 2, acin1a, GRIM19, TP53INP1, septin 3, cyclin G1, cdca3, and bax (Additional Files 1 and 2). Three genes encoding for nucleobindin $2 \mathrm{a}$, growth arrest-specific 8 , and cyclin G1 and associated with cell cycle and cell growth, showed the most consistent and significant induction across all stress treatments examined (Figure 3), making them good candidates for molecular stress biomarkers in P. moluccensis.

Gene functions related to protein turnover, such as 'regulation of translation', 'protein folding', and 'ubiquitindependent protein catabolism', were also commonly 
Table I: Results of gene set analysis of gene expression responses to environmental stress in Pomacentrus moluccensis

\begin{tabular}{|c|c|c|c|c|c|c|c|c|c|}
\hline \multirow{2}{*}{$\begin{array}{l}\text { Gene } \\
\text { Ontology/GO } \\
\text { ID }\end{array}$} & \multirow{2}{*}{$\begin{array}{c}\text { \# of } \\
\text { probes on } \\
\text { array }\end{array}$} & \multirow{2}{*}{$\begin{array}{l}\text { \# of genes } \\
\text { on array }\end{array}$} & \multicolumn{7}{|c|}{ p-value (FDR-corrected) } \\
\hline & & & $31^{\circ} \mathrm{C} 5 \mathrm{~d}$ & $22^{\circ} \mathrm{C} 3 \mathrm{~h}$ & $31^{\circ} \mathrm{C} 3 \mathrm{~h}$ & $\begin{array}{c}34^{\circ} \mathrm{C} 3 \mathrm{~h} \\
\text { sum. }\end{array}$ & $\begin{array}{c}34^{\circ} \mathrm{C} 3 \mathrm{~h} \\
\text { winter }\end{array}$ & Hypoxia & Hyposm. \\
\hline \multicolumn{10}{|l|}{$\begin{array}{l}\text { Cell growth } \\
\text { and } \\
\text { Cytoskeleton }\end{array}$} \\
\hline $\begin{array}{l}\text { Actin } \\
\text { cytoskeleton } \\
\text { organization/ } \\
\text { GO:0030036 }\end{array}$ & 253 & 81 & 0.019 & 0.000 & 0.000 & 0.000 & 0.000 & 0.000 & 0.013 \\
\hline $\begin{array}{l}\text { Anti-apoptosis/ } \\
\text { GO:0006916 }\end{array}$ & 76 & 72 & 0.017 & 0.000 & 0.079 & 0.033 & 0.025 & 0.000 & 0.065 \\
\hline $\begin{array}{l}\text { Induction of } \\
\text { apoptosis/ } \\
\text { GO:0006917 }\end{array}$ & 75 & 73 & 0.001 & 0.001 & 0.034 & 0.007 & 0.002 & 0.220 & 0.000 \\
\hline $\begin{array}{l}\text { Cell growth/ } \\
\text { GO:0016049 }\end{array}$ & 65 & 63 & 0.044 & 0.000 & 0.454 & 0.000 & 0.001 & 0.075 & 0.167 \\
\hline $\begin{array}{l}\text { Mitotic cell } \\
\text { cycle/ } \\
\text { GO:0000278 }\end{array}$ & 30 & 30 & 0.106 & 0.082 & 0.572 & 0.127 & 0.027 & 0.069 & 0.417 \\
\hline \multicolumn{10}{|l|}{$\begin{array}{l}\text { Protein } \\
\text { turnover }\end{array}$} \\
\hline $\begin{array}{l}\text { Regulation of } \\
\text { translation/ } \\
\text { GO:0006445 }\end{array}$ & 82 & 81 & 0.000 & 0.000 & 0.002 & 0.005 & 0.000 & 0.001 & 0.012 \\
\hline $\begin{array}{l}\text { Ubiquitin- } \\
\text { dependent } \\
\text { protein } \\
\text { catabolism/ } \\
\text { GO:00065II }\end{array}$ & 98 & 96 & 0.200 & 0.092 & 0.024 & 0.002 & 0.001 & 0.003 & 0.011 \\
\hline $\begin{array}{l}\text { Protein folding/ } \\
\text { GO:0006457 }\end{array}$ & 75 & 74 & 0.000 & 0.191 & 0.005 & 0.000 & 0.002 & 0.000 & 0.446 \\
\hline \multicolumn{10}{|l|}{ Metabolism } \\
\hline $\begin{array}{l}\text { Carbohydrate } \\
\text { metabolism/ } \\
\text { GO:0005975 }\end{array}$ & 67 & 67 & 0.057 & 0.217 & 0.076 & 0.011 & 0.000 & 0.001 & 0.088 \\
\hline $\begin{array}{l}\text { Lipid } \\
\text { metabolism/ } \\
\text { GO:0006629 }\end{array}$ & 75 & 75 & 0.001 & 0.113 & 0.007 & 0.000 & 0.000 & 0.127 & 0.018 \\
\hline $\begin{array}{l}\text { Glycolysis/ } \\
\text { GO:0006096 }\end{array}$ & 31 & 31 & 0.319 & 0.598 & 0.304 & 0.127 & 0.009 & 0.086 & 0.226 \\
\hline $\begin{array}{l}\text { Gluconeogenesis } \\
\text { /GO:0006094 }\end{array}$ & 21 & 21 & 0.644 & 0.408 & 0.353 & 0.154 & 0.013 & 0.087 & 0.430 \\
\hline \multicolumn{10}{|l|}{ Stress } \\
\hline $\begin{array}{l}\text { Response to } \\
\text { pest, pathogen } \\
\text { or parasite/ } \\
\text { GO:00096/3 }\end{array}$ & 92 & 89 & 0.000 & 0.000 & 0.000 & 0.000 & 0.000 & 0.000 & 0.024 \\
\hline $\begin{array}{l}\text { Response to } \\
\text { temperature } \\
\text { stimulus/ } \\
\text { GO:0009266 }\end{array}$ & 57 & 52 & 0.023 & 0.148 & 0.001 & 0.000 & 0.010 & 0.163 & 0.225 \\
\hline $\begin{array}{l}\text { Osmoregulation } \\
\text { GO:0018987 }\end{array}$ & 16 & 16 & 0.272 & 0.136 & 0.162 & 0.035 & 0.067 & 0.457 & 0.178 \\
\hline $\begin{array}{l}\text { Response to } \\
\text { oxidative stress/ } \\
\text { GO:0006979 }\end{array}$ & 22 & 22 & 0.072 & 0.306 & 0.274 & 0.270 & 0.865 & 0.273 & 0.239 \\
\hline \multicolumn{10}{|l|}{ Other } \\
\hline $\begin{array}{l}\text { DNA repair/ } \\
\text { GO:000628I }\end{array}$ & 84 & 84 & 0.115 & 0.040 & 0.291 & $0.08 I$ & 0.000 & 0.068 & 0.365 \\
\hline
\end{tabular}


Table I: Results of gene set analysis of gene expression responses to environmental stress in Pomacentrus moluccensis (Continued)

\begin{tabular}{|c|c|c|c|c|c|c|c|c|c|}
\hline $\begin{array}{l}\text { Hemoglobin } \\
\text { complex/ } \\
\text { GO:0005833 }\end{array}$ & 16 & 11 & 0.017 & 0.651 & 0.227 & 0.027 & 0.050 & 0.151 & 0.446 \\
\hline
\end{tabular}

For each gene ontology an aggregate score was computed based on the p-values for differential expression of the genes in that category. The significance of the resulting gene set score was determined by random sampling of the data using the software ermine] [72]. P-values are FDRcorrected with values smaller than 0.1 indicated in bold. " $3 \mathrm{~h}$ " indicates three hour exposure," $5 \mathrm{~d}$ " five day exposure to stressor, 'sum." refers to exposure experiments performed in summer, "Hyposm." refers to hyposmotic exposure experiments.

associated with the gene responses of $P$. moluccensis to stress. Individual genes that contributed to this component of the common stress response included pdip5, USP29, psmc3, fbxl12, the translation initiation factors eif $2 b 2$, eif $2 c 1$, eif $4 b$, and the ribosomal proteins rps6, mrpl30, mrpl36. Stress can increase rates of protein damage and ubiquitin-dependent protein catabolism [19,29,30]. Association of the gene functions 'protein folding' and 'ubiquitin-dependent protein catabolism' with gene responses observed in this study suggest that environmental stress leads to increased protein damage, an adjustment of the proteome, and de novo synthesis of proteins in this species. Protein synthesis in ectotherms accounts for about 20 percent of the cellular energy budget [30,31]. De novo protein synthesis and protein repair in response to environmental stress are thus likely to incur substantial energetic costs in P. moluccensis and may reduce the energy available for other organismal functions such as growth and reproduction. These results are concordant with studies of the yeast Saccharomyces cerevisiae that have shown that yeast responds to a range of environmental stressors with a stereotypical change in gene expression and the suppression of around ten percent of assayed genes, many of which function in protein synthesis and cell growth [32].

A third group of gene functions commonly associated with environmental stress responses in $P$. moluccensis included metabolic gene functions, in particular gene functions related to carbohydrate and lipid metabolism. Stress-responsive genes with metabolic functions included SC4MOL, CHST2, amy2a, ACAD, dgat2l, dcxr, and fuca1. Metabolic adjustments and the re-allocation of energy resources may reflect mechanisms that allow for increased levels of protein and cellular repair during stress.

Genes with stress-related functions, and functions in cellular repair, were also commonly associated with transcriptional stress responses in $P$. moluccensis, and included dnajb11, peroxiredoxin 6, ptges3, apoea, hif1 an, and a gene encoding elastase 2. Elastase 2 hydrolyses collagen-IV and elastin and its activity has been shown to increase in the presence of reactive oxygen species [33]. Regulation of elastase 2, therefore, suggests increased levels of oxidative stress under conditions of environmental stress. In addition, genes with immune functions and the gene ontology 'response to pest, pathogen or parasite' were commonly associated with environmental stress responses, suggesting a challenge to the immune system. This functional category included the genes CHST2, T-cell receptor alpha, and haptoglobin. Finally, the gene function 'DNA repair' was significantly associated with many of the stress responses measured here, suggesting increased levels of DNA damage under conditions of environmental stress. Such responses are consistent with the observation that different types of stress can lead to immunosuppression [34,35] and genotoxic effects [36].

Here we have shown that a multi-stressor approach, and the identification of gene functions most often associated with gene expression responses to stress, can enhance our understanding of the biological processes altered by environmental stress. Our results suggest that common effects of environmental stress in P. moluccensis include suppression of cell growth, increased protein damage and de novo synthesis of proteins, metabolic adjustments and a reallocation of energy resources possibly related to increased protein and cellular repair, induction of stress genes and cellular repair systems, and a challenge of immune functions. Different types of stressors have been previously associated with a 'minimal stress proteome', comprised in particular of proteins involved in DNA, protein and molecular repair and energy metabolism [37]. Our results therefore provide experimental support for the presence of a stress proteome, and common stress responses, also in an ectothermic vertebrate, the coral reef fish Pomacentrus moluccensis.

\section{Early gene responses to environmental stress}

In addition to the common stress responses discussed above, there were also differences between the responses to individual stressors. For example, there was a remarkable difference in the number of genes that were regulated in response to heat shock at $34^{\circ} \mathrm{C}$ in summer and winter. Mean winter and summer temperatures differ by approximately $4^{\circ} \mathrm{C}$ at the study site. Seasonal acclimation can lead to extensive transcriptional adjustments in teleosts [38-41] and may thus account for some of the transcriptional differences observed here. We cannot exclude, however, the possibility that some of the changes in gene expression were due to the male fish employed in the 
Table 2: Results of over-representation analysis of gene ontologies

\begin{tabular}{|c|c|c|c|c|c|c|}
\hline Gene Ontology & GO ID & $\begin{array}{c}\text { Number of } \\
\text { probes on array }\end{array}$ & $\begin{array}{c}\text { Number of } \\
\text { genes on array }\end{array}$ & $\begin{array}{l}\text { Number of } \\
\text { genes in gene } \\
\text { cluster }\end{array}$ & Raw p-value & $\begin{array}{l}\text { FDR-corrected } \\
\text { p-value }\end{array}$ \\
\hline \multicolumn{7}{|c|}{ Cluster I-Immune Function and Development } \\
\hline $\begin{array}{l}\text { MHC class I } \\
\text { protein binding }\end{array}$ & GO:0042288 & 7 & 7 & 2 & 0.0000 & 0.0561 \\
\hline $\begin{array}{l}\text { Neurite } \\
\text { morphogenesis }\end{array}$ & GO:0048812 & 62 & 60 & 3 & 0.0032 & 0.1289 \\
\hline $\begin{array}{l}\text { Cell fate } \\
\text { determination }\end{array}$ & GO:000I709 & 59 & 45 & 2 & 0.0106 & 0.1807 \\
\hline \multicolumn{7}{|c|}{ Cluster II-Cell Growth } \\
\hline $\begin{array}{l}\text { Vesicle transport } \\
\text { along actin } \\
\text { filament }\end{array}$ & GO:0030050 & 181 & 9 & 2 & 0.0000 & 0.0251 \\
\hline SWRI complex & GO:00008I2 & 182 & 10 & 2 & 0.0000 & 0.0119 \\
\hline $\begin{array}{l}\text { Cortical actin } \\
\text { cytoskeleton }\end{array}$ & GO:0030864 & 183 & 11 & 2 & 0.0000 & 0.0122 \\
\hline $\begin{array}{l}\text { Condensed } \\
\text { nuclear } \\
\text { chromosome }\end{array}$ & GO:0000794 & 13 & 13 & 2 & 0.0001 & 0.0168 \\
\hline $\begin{array}{l}\text { Histone } \\
\text { acetylation }\end{array}$ & GO:0016573 & 186 & 14 & 2 & 0.0001 & 0.0178 \\
\hline Actin filament & GO:0005884 & 187 & 15 & 2 & 0.0001 & 0.0190 \\
\hline Meiosis & GO:0007I26 & 51 & 51 & 3 & 0.0002 & 0.0269 \\
\hline $\begin{array}{l}\text { M phase of mitotic } \\
\text { cell cycle }\end{array}$ & GO:0000087 & 97 & 96 & 3 & 0.0024 & 0.0779 \\
\hline \multicolumn{7}{|c|}{ Cluster III-Metabolism } \\
\hline Sterol metabolism & GO:0016125 & 12 & 12 & 3 & 0.0000 & 0.0001 \\
\hline Trypsin activity & GO:0004295 & 14 & 14 & 3 & 0.0000 & 0.0001 \\
\hline $\begin{array}{l}\text { Positive regulation } \\
\text { of protein metab. }\end{array}$ & GO:005I247 & 18 & 18 & 3 & 0.0000 & 0.0002 \\
\hline $\begin{array}{l}\text { Cholesterol } \\
\text { metabolism }\end{array}$ & GO:0008203 & 18 & 18 & 3 & 0.0000 & 0.0002 \\
\hline \multicolumn{7}{|l|}{ Cluster IV-Stress } \\
\hline Lytic vacuole & GO:0000323 & 42 & 42 & 3 & 0.0001 & 0.2378 \\
\hline Lysosome & GO:0005764 & 54 & 54 & 3 & 0.0004 & 0.3168 \\
\hline Response to UV & GO:00094II & 6 & 5 & I & 0.0004 & 0.1620 \\
\hline $\begin{array}{l}\text { Replicative cell } \\
\text { aging }\end{array}$ & GO:000I302 & 5 & 5 & 1 & 0.0004 & 0.1296 \\
\hline $\begin{array}{l}\text { Response to water } \\
\text { deprivation }\end{array}$ & GO:00094|4 & 5 & 5 & 1 & 0.0004 & 0.1080 \\
\hline $\begin{array}{l}\text { Response to } \\
\text { reactive oxygen } \\
\text { species }\end{array}$ & GO:0000302 & 7 & 7 & 1 & 0.0008 & 0.1349 \\
\hline
\end{tabular}

We tested for significant over-representation of gene ontologies of genes within a cluster compared to the total complement of genes represented on the microarray. Gene clusters were identified by hierarchical clustering of significant gene responses across stressors (see Figure 3 for cluster identification)

microarray analyses being at different stages of the reproductive cycle at the time of sampling. The different experimental designs employed in the summer and winter analyses (see Methods) may have further confounded these results as biological samples had been pooled in the winter analyses, but not in the summer analyses. Further studies will be required to more precisely define the sources of these differences in stress responses between summer and winter.
Many responses to hypoxia compensate for reduced cellular oxygen levels by increasing capacities for oxygen delivery, and by enhancing oxygen-independent ATP production by means of glycolysis [42]. The hypoxiainducible transcription factor HIF-1 plays an important role in coordinating transcriptional responses to hypoxia [42-47]. In the present study, HIF-1a showed only limited gene regulation (data not shown) which is consistent with HIF regulation occurring largely at the protein level, not at the mRNA expression level. However, hypoxia-inducible factor 1 alpha subunit inhibitor (HIF1an), which 


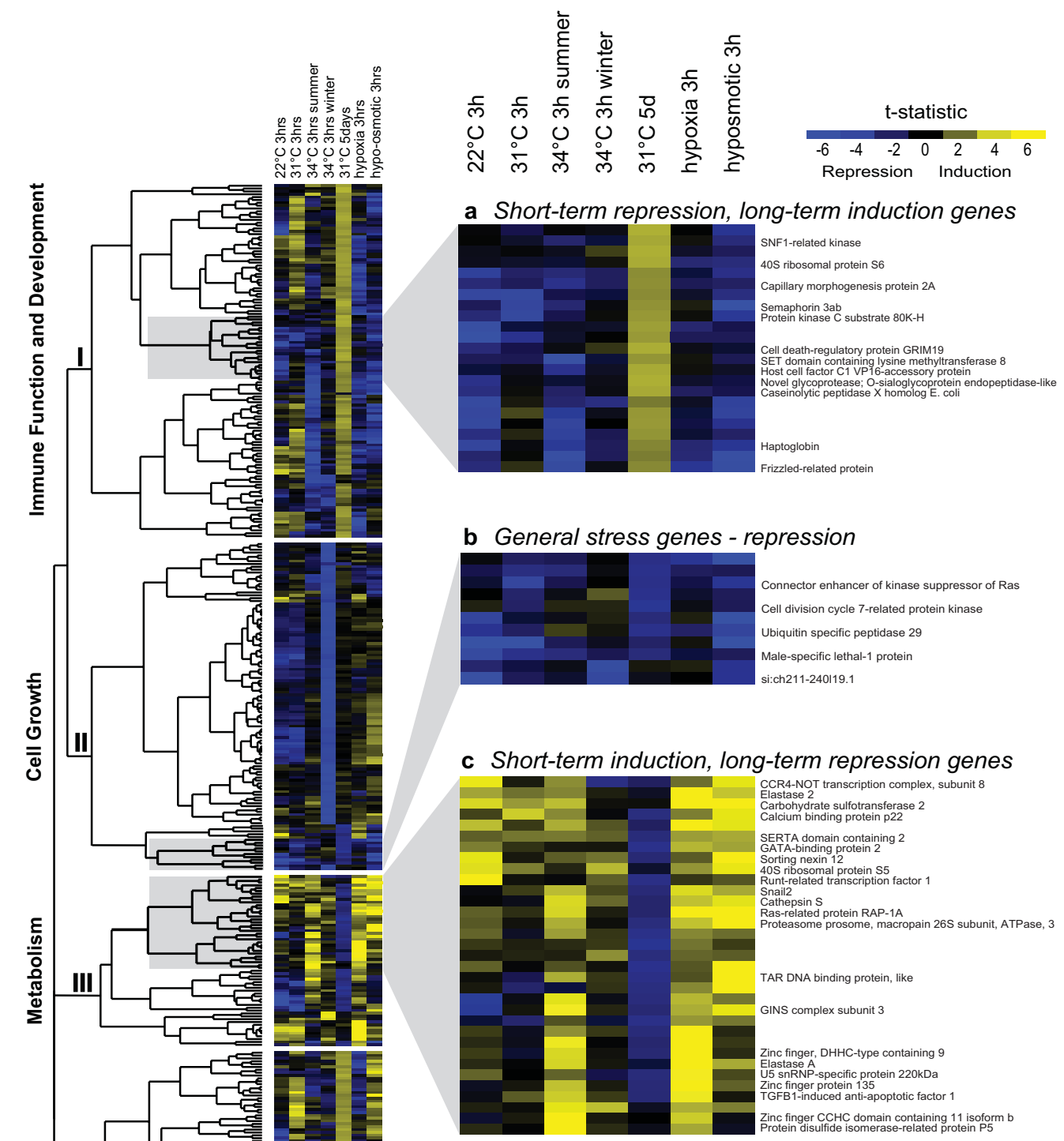

d General stress genes - induction

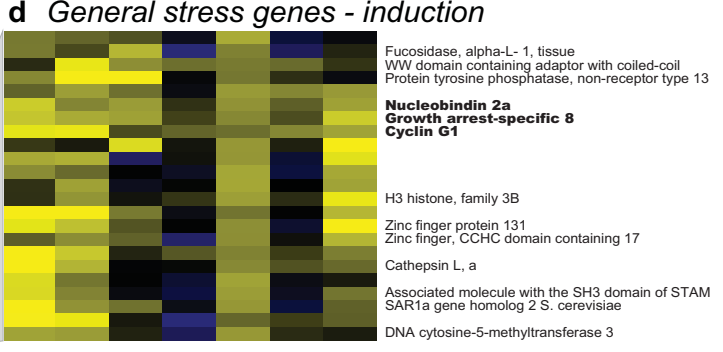

Figure 3

Hierarchical clustering of genes showing significant gene regulation in response to environmental stress. The results of hierarchical clustering of genes that showed differential expression in response to different types of environmental stress in Pomacentrus moluccensis are shown in form of a heat map. Values presented are the values of the t-statistic summarising the expression responses across biological replicates. Where spots on the microarray could be unambiguously annotated with gene names, these are given to the right of the corresponding row in the heat map. Three genes that showed the most consistent induction across stress treatments are in bold. " $3 \mathrm{~h}$ " indicates three hour exposure, " $5 \mathrm{~d}$ " five day exposure to stressor. 
modulates HIF-1 transcriptional activity, was significantly down-regulated in response to prolonged heat exposure (Additional File 1). While further data are required to understand the role of HIF-1 $a$ and HIF1an in response to hypoxic and heat stress in P. moluccensis, association of the gene ontologies 'glycolysis' and 'gluconeogenesis' with the response to hypoxia is consistent with the need to increase oxygen-independent ATP production. Furthermore, amongst the most significant expression responses to hypoxia was induction of amy $2 a$, encoding the amylase-3 protein that endohydrolyses $1,4-\alpha$-D-glucosidic linkages in polysaccharides such as starch and glycogen to make dextrin, which can then be reduced to $\alpha$-D-glucose. During hypoxia, this protein appears to free stored sugars for use in glycolysis and would, therefore, facilitate oxygenindependent ATP production.

\section{Gene expression responses to prolonged heat}

Given current models of climatic change and the prediction of rising sea surface temperatures, we were particularly interested in gene responses to prolonged heat, and how early gene responses may change following prolonged exposure to heat. We found that while the gene ontology 'protein folding' remained associated with the response to heat even after prolonged exposure 'ubiquitin-dependent protein catabolism' was not. These results suggest that initial adjustments of the proteome during stress involve increased degradation of (stress-damaged) proteins and increased levels of ubiquitin-dependent protein catabolism. Over time, rates of protein catabolism appear to return to baseline levels, while protein chaperone systems remain induced.

Prolonged heat exposure was further associated with the gene ontology 'response to oxidative stress' and induction of the genes encoding peroxiredoxin 6 and apolipoprotein $\mathrm{Ea}$, two proteins with antioxidant function. Oxidative stress is caused by the formation of reactive oxygen species and has been associated with many forms of stress $[6,7,20,48-54]$. It is likely that oxidative stress, and the associated cellular and molecular damage, incur substantial energetic costs during prolonged heat exposure. The fact that the gene ontologies 'carbohydrate metabolism' and 'lipid metabolism' remain associated with gene responses even after prolonged exposure to heat may reflect long-term re-allocation of energy resources. Such energetic re-organisation may compensate for the energetic needs associated with protein and cellular repair arising from prolonged heat exposure and the associated oxidative stress. For example, ACAD, dgat $2 l$, dcxr, HADH2, crabp2, Glb1, elovl6l, fuca1, and AGPAT3 all encode proteins that function in carbohydrate or lipid metabolism and were regulated in response to prolonged heat.
Stress commonly suppresses immune function and chronic stress is typically associated with an increased risk of developing pathologies $[34,35]$. The association of 'response to pest, pathogen or parasite' with gene responses to prolonged heat suggests a continuous challenge of the immune system, and potentially, an elevated risk of disease. The ontology 'hemoglobin complex' was also associated with the response to prolonged heat suggesting that prolonged heat exposure may compromise oxygen supply. During heat stress, oxygen demand can exceed oxygen supply, leading to hypoxia in the cells $[2,55]$. Genes encoding hemoglobin beta embryonic-1, hemoglobin alpha embryonic-3, and haptoglobin were induced in response to prolonged heat in this study, likely reflecting this need to enhance oxygen delivery systems during heat stress. Our data suggest that prolonged heat exposure in the coral reef fish $P$. moluccensis is associated with oxidative stress, proteomic and metabolic adjustments, an induction of oxygen delivery systems, and a challenge of immune functions.

\section{Conclusion}

Understanding thermal and environmental stress responses in coral reef fishes is paramount as current models of climate change predict a significant rise in sea surface temperatures within the next decades [56]. The predicted rise in sea surface temperatures adds to other anthropogenic threats, which have already significantly affected the functionality of coral reef ecosystems [57-59], and may lead to increased levels of physiological stress and mortality in coral reef organisms. For example, elevated sea surface temperatures a few degrees Celsius above normal can lead to coral bleaching [60]. While we have recently gained considerable knowledge about the relationship between sea surface temperatures and the incidence of coral bleaching, we presently have only limited data to estimate the potential effects of elevated temperatures on the physiology of coral reef fishes and, in particular, how heat alters biological function in these fishes. Our results provide the first evidence that the transcriptome and biological function of coral reef fishes can be significantly altered in response to a three-degree Celsius increase in temperature. Such a temperature rise is well within the range of predicted temperature increases of current climate change models. It is possible that the responses to heat observed here are altered following longer-term exposure. Further research is needed, therefore, to investigate the longer-term effects of increased temperatures on gene regulation as well as on growth, reproduction, and immune function. Since the functions of many heat-responsive genes are still unknown, experimental characterisation of gene functions during stress would also enhance our understanding of the effects of elevated temperatures on coral reef fishes and other ectothermic vertebrates. Future work may also establish closer 
links between the genome and phenome under conditions of environmental stress by relating liver gene responses to those observed in other tissues and by estimating the severity of stress using other indicators, such as blood cortisol levels or the expression of heat shock proteins. In addition, future work may investigate the changes in transcriptional regulation over the full time course of the biological response, from a few minutes to several weeks and months of exposure. Irrespective of the complexity of environmental stress responses discussed above, this study has demonstrated that there are a set of gene functions commonly associated with environmental stress responses in a warm-adapted ectothermic vertebrate, that these common responses are effectuated by a largely independent set of genes, and that the multi-stressor approach applied here is useful for delineating common responses from those unique to different types of environmental stress. A more complete understanding of environmental stress responses in ectothermic vertebrates will depend on the successful integration of environmental genomic data with data obtained from cellular, physiological and organismal studies, and our ability to unravel the complex interactions that occur between different levels of biological organisation.

\section{Methods}

\section{Stress experiments}

Summer-acclimated adult $P$. moluccensis were collected around Lizard Island, northern Great Barrier Reef, Australia ( $\left.14^{\circ} 40^{\prime} \mathrm{S}, 145^{\circ} 28^{\prime} \mathrm{E}\right)$ by divers on SCUBA using barrier and scoop nets and transferred to the Lizard Island Research Station. Fish were housed in groups of up to 20 individuals in aquaria supplied with flow-through seawater at ambient temperature (approximately $28^{\circ} \mathrm{C}$ ). Sections of PVC pipes and dead branching coral were provided for shelter. After two days of acclimation to these conditions, animals were transferred to individual aquaria of $31^{\circ} \mathrm{C}$ for five days or remained at ambient temperature $\left(28^{\circ} \mathrm{C}\right)$ for five days. We exposed additional P. moluccensis individuals to heat shock at $31^{\circ} \mathrm{C}$ or $34^{\circ} \mathrm{C}$, cold shock at $22^{\circ} \mathrm{C}$, hypoxia (23-36\% air saturation), or hyposmotic conditions (20 ppt salinity) for three hours. Hypoxic conditions were created by applying a constant flow of nitrogen to the tanks. Hyposmotic conditions were created by mixing seawater with distilled water, reducing the salinity of the seawater from $36 \mathrm{ppt}$ to $20 \mathrm{ppt}$. The maximum range of naturally occurring environmental conditions for this population of coral reef fish are temperatures between $24^{\circ} \mathrm{C}$ in winter and $30^{\circ} \mathrm{C}$ in summer, air saturation around $100 \%$, but possibly as low as 20\% deep in branching coral at night [61], and salinities between $34 \mathrm{ppt}$ and $36 \mathrm{ppt}$. All treatments were associated with behavioural changes such as increased ventilation rates and gasping for air at the surface. All experiments performed in this study, therefore, appear to have induced a physiological challenge in these experimental subjects and the gene responses observed are very likely to constitute a stress response.

It is practically impossible to measure transcriptional responses to a variety of stressors across the full time course of a biological response. Therefore, we have focused here on two time points of particular interest. The five-day heat exposure experiments targeted responses beyond the primary responses measured using only threehour exposure. On any one day, an equal number of fish were subjected to either one of the stress treatments or transferred to aquaria at ambient conditions, in order to provide time-matched controls. We have previously performed a severe heat shock treatment at $34^{\circ} \mathrm{C}$ with winteracclimated $P$. moluccensis [23]. We were thus able to compare summer and winter responses to severe heat shock (ambient conditions were $26^{\circ} \mathrm{C}$ in winter and $28^{\circ} \mathrm{C}$ in summer). Following these treatments, fish were killed by placing them on ice. Livers were excised immediately following killing of fish in order to avoid any potential decay of RNA and the RNA was stored in RNAlater ${ }^{\mathrm{TM}}$ (Qiagen) for microarray analysis. While we used liver for the analysis of gene expression responses, other tissues may have been affected differently. However, liver is a metabolically important tissue and should thus provide insight into a large number of transcriptional responses. We further assumed that gene expression changes measured using this approach are indicative of the types of biological functions affected by environmental stress, independent of how changes at the mRNA level may relate to changes in protein expression. Since age and gender can affect expression responses, we restricted the analyses of gene responses to males of similar standard length, assuming that similar standard length would indicate similar age. Hence, only adult male fish of standard length $47 \pm 4 \mathrm{~mm}$ were used in the microarray analyses.

\section{Microarray analysis}

The Compugen $16 \mathrm{~K} \mathrm{D}$. rerio oligonucleotide array was previously shown to be useful for studying gene responses in P. moluccensis. Quantitative real-time PCR confirmed differential gene expression for identified candidate genes and comparative genomic hybridisation experiments showed good cross-hybridisation for most genes between the two fish species [23]. This microarray represents one of the largest teleost microarrays available containing 16,399 oligos (65-oligomers) representing 15,806 unique $D$. rerio gene clusters plus controls. This array offered, therefore, the greatest chance of detecting large numbers of genes involved in transcriptional responses to stress. The arrays were printed by the Adelaide Microarray Facility. The list of genes immobilised on the array is available at [62]. 
Total RNA from liver tissue of stressed P. moluccensis and $P$. moluccensis kept at ambient conditions was extracted using TRIzol ${ }^{\circledast}$ (Invitrogen) according to the manufacturer's instructions and purified using RNeasy ${ }^{\mathrm{TM}}$ columns (Qiagen), ethanol-precipitated and subsequently resuspended in nuclease-free water. The concentration and purity of RNA was determined by spectrophotometer readings at 260 and $280 \mathrm{~nm}$. The integrity of the RNA was confirmed by agarose gel electrophoresis. All samples used in the microarray analyses were of highest RNA quality with no apparent signs of RNA degradation. Forty $\mu \mathrm{g}$ of total RNA were reverse transcribed and labelled using the SuperScript Plus Indirect cDNA Labeling System (Invitrogen) according to the manufacturer's instructions. Both oligo dT and random hexamers were used for priming of the reverse transcription reaction and Alexa Fluor ${ }^{\circledR} 555$ and Alexa Fluor ${ }^{\circledR} 647$ dyes (Invitrogen) were used for labelling. Prior to hybridisation, each microarray slide was immersed in distilled water at $60^{\circ} \mathrm{C}$ for $5 \mathrm{~min}$ and dried by centrifugation at $650 \times \mathrm{g}$ for $5 \mathrm{~min}$. The purified fluorescently labelled cDNA samples were mixed with 5 $\mu \mathrm{g}$ human Cot-1 and $8 \mu \mathrm{g}$ poly $\mathrm{A}$, dried under reduced pressure, resuspended in $14 \mu \mathrm{l}$ formamide and $14 \mu \mathrm{l}$ of $6.25 \times \mathrm{SSC}$, denatured by heating to $100^{\circ} \mathrm{C}$ for $3 \mathrm{~min}$ and transferred directly to ice. Finally, $0.6 \mu \mathrm{l}$ of $10 \%(\mathrm{w} / \mathrm{v})$ SDS was added to each sample. The probes were applied to the arrays and incubated at $42^{\circ} \mathrm{C}$ overnight in a humidified chamber. The arrays were washed in $0.5 \times$ SSC containing $0.01 \%(\mathrm{w} / \mathrm{v})$ SDS for $1 \mathrm{~min}, 0.5 \times$ SSC for $3 \mathrm{~min}$ and $0.2 \times$ SSC for $3 \mathrm{~min}$. The slides were scanned using an Axon 4000B microarray scanner. Single image tif files were saved for data analysis.

In total, 59 microarray hybridisations representing 118 individual $P$. moluccensis were performed using dye swaps and an approximately balanced design (Figure 4). While the aim of the study was to identify gene regulation in response to environmental stress using expression levels of fish kept at ambient conditions as reference, direct comparisons involving two stress treatments were included to make the experimental design more robust to the potential failure of some microarray hybridisations and to facilitate direct comparison between stress treatments. Based on the results of comparative genomic hybridisations, 985 of the 16,897 array spots were excluded from analysis of the microarray data because these spots showed poor cross-hybridisation between $P$. moluccensis and the D. rerio microarray [23]. For the remainder of the spots on the array, the red and green fluorescent signal intensities were extracted using SPOT software (CSIRO Mathematical and Information Sciences, Australia). The data were background corrected using the Spot morphological close/open method. Spot weights were calculated on the basis of the number of pixels in the spot, with spot areas between 30 and 300 pixels given full weight. The ratio of the resultant signal intensities (red/ green) was $\log _{2}$-transformed. Statistical analyses were performed using the software package LIMMA [63] implemented in the $\mathrm{R}$ statistical software environment, following Smyth [64]. The transformed signal intensities of each grid on the array and global signal intensity were print-tip Loess normalised [65], and scale normalised between arrays. Loess normalisation subtracts a Loess regression curve from the MA-transformed data in order to remove dye bias from the data, while scale normalisation between arrays ensures that signal intensities are comparable across arrays. A moderated t-statistic was calculated for each gene on the array using an empirical Bayes method [64]. Benjamini and Hochberg's [66] method for controlling the false discovery rate (FDR) was used to control experiment-wide Type I error rates in the face of multiple testing. Genes with FDR-adjusted p-values $<0.1$ were categorised as differentially expressed.

Within-ambient comparisons were performed to test whether fish treated on different days showed significantly different expression patterns (Figure 4). Pooling of ambient controls is justified where expression levels are consistent across them. Therefore, a linear model was fitted to the expression data with the ambient controls from the $31^{\circ} \mathrm{C}$ three hours treatment group used as a reference. Moderated t-statistics and F-statistics measuring the overall significance of the between-control contrasts were calculated [64]. Holm's method was used to adjust p-values for multiple testing [67]. The purpose here was to test whether there were significant differences between fish kept at ambient conditions on different days. Four genes had an adjusted p-value of less than 0.1. Three of these genes occupied neighbouring spots on the arrays. Two microarrays were outliers for these spots indicated by the residual $M$-value from the model. After removing these two arrays and refitting the linear model, only one spot remained significantly different amongst control groups. We decided to retain this microarray, but treat conclusions about this gene with caution. For the remaining analyses, ambient control samples were pooled and used as an ambient reference.

Gene annotation was performed using the program Resourcerer 12.0 [68]. Gene function of identified candidate genes was estimated by gene functions determined for $D$. rerio using a combination of AmiGo [69], iHop [70], and databases at NCBI [71].

\section{Identification of gene functions responsive to stress}

To test whether genes of a certain function were more likely to be differentially expressed in response to different environmental stressors than expected if differential expression was independent of gene function, we used gene class testing and the gene set resampling (GSR) 


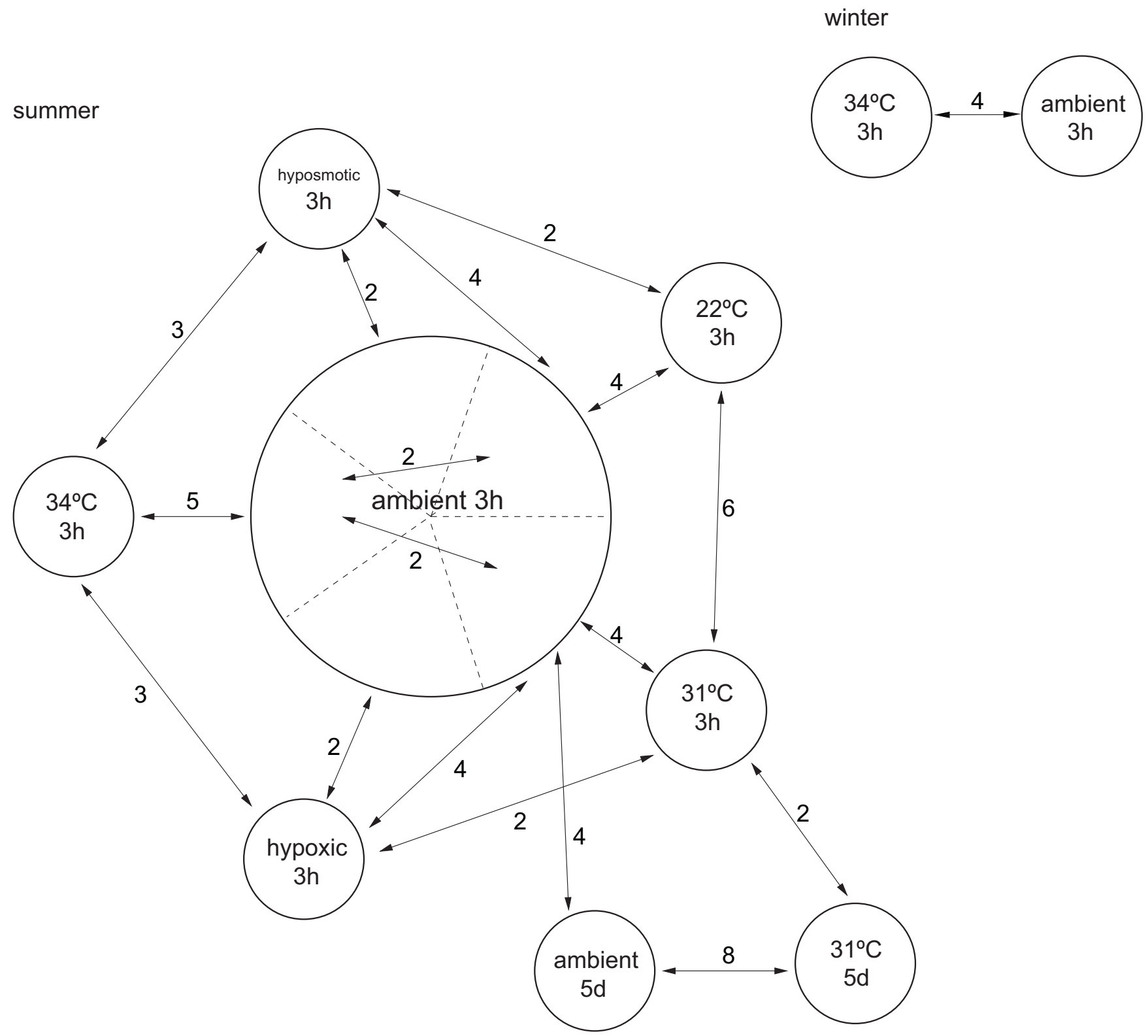

Figure 4

Experimental design of the multi-stressor approach to investigate environmental stress responses. The experiments were performed in an ectothermic vertebrate, the coral reef fish Pomacentrus moluccensis. Text within each circle names the stress and the duration it was applied, being three hours $(3 \mathrm{~h})$ or five days $(5 \mathrm{~d})$. Numbers above arrows indicate the number of microarray hybridisations used in the analysis of gene expression changes. Each microarray hybridisation compared relative expression levels in two samples (two-colour microarray analysis). Each sample in the microarray hybridisations represented one individual fish (no sample pooling) and a total of I 18 individual fish were analysed in this study. Arrowheads indicate use of Alexa Fluor ${ }^{\circledR} 555$ dye (green), which was swapped between samples to account for potential dye bias. The dotted lines within the ambient $3 \mathrm{~h}$ group indicate five groups of fish exposed to ambient conditions on separate days in order to provide time-matched controls for each of the stress treatments. Ambient conditions were $28^{\circ} \mathrm{C}$ in summer and $26^{\circ} \mathrm{C}$ in winter.

algorithm implemented in the software ermineJ [72]. In contrast to other commonly used gene class testing algorithms, the gene set resampling algorithm does not require a threshold for gene selection. Instead, all genes belonging to a particular gene ontology class are used to compute a raw score $r=-\sum i \log (p i)$, where $p i$ is the $p$-value 
for differential expression for each gene in the gene ontology class. Thus, GSR employs the continuous evidence contained in the p-values for differential expression and is the method of choice for gene class testing where there is no a priori gene grouping information. Gene ontology classes of size $\mathrm{k}=5-100$ were examined. For genes that were represented multiple times on the array, the minimum p-value was used. In order to calculate the distribution of raw scores under the null hypothesis of random distribution of gene ontologies, a random set of genes of the same size as each of the gene classes of interest was drawn from the data and the raw score $r$ was computed for the random set. We performed one million iterations of this procedure. The significance for a gene set class was calculated as the fraction of random trials resulting in a score higher than $r$ and the resulting $p$-values for overall significance were FDR-corrected.

\section{Hierarchical clustering and visualisation of gene responses across treatments}

Unsupervised hierarchical clustering and the software programs Cluster and TreeView [73] were used to organise differentially expressed genes into groups of co-regulated genes. Array- and gene-normalised values of the t-statistic and complete linkage uncentered correlation were employed for clustering. The values of the t-statistic were chosen over average $\mathrm{M}$-values, because the t-statistic not only reflects the magnitude of the average expression change, but also retains information on the variability in expression response across biological replicates. Visualisation of $\mathrm{M}$-values representing individual arrays was not appropriate in this study because both direct and indirect comparisons were used for estimation of stress expression responses and indirect comparisons could not be unambiguously assigned to individual stress treatments.

To test for a relationship between cluster identity and gene function, we performed over-representation analysis (ORA) implemented in the software ermineJ [72]. The ORA algorithm is most appropriate here because the genes for this analysis naturally fell into two groups, being either in the cluster of interest or not. Gene functions of genes that were part of the cluster in question were compared to the gene functions of all genes represented on the microarray and we tested for a significant over-representation of gene functions amongst genes within a cluster.

\section{Competing interests}

The author(s) declares that there are no competing interests.

\section{Authors' contributions}

KSK, RHC and MJC conceived and designed this study. KSK and GS performed the statistical analyses. ACW provided the microarrays for use in this study. KSK performed the field and microarray experiments and prepared the manuscript. RHC, MJC, GS, and ACW helped to draft the manuscript. All authors read and approved the final manuscript.

\section{Additional material}

\section{Additional file 1}

Changes in mRNA levels in Pomacentrus moluccensis exposed to three-hour stress treatments compared to P. moluccensis kept at ambient conditions. GenBank accession numbers refer to the Danio rerio clones represented on the microarray. Statistical significance was determined using Bayesian analysis of the expression response across biological replicates ( $p$-values are FDR-corrected). Negative values of fold change indicate down-regulation of gene in stressed $\mathrm{P}$. moluccensis, while positive values indicate up-regulation. Only genes with FDR-corrected p-values $<0.1$ and genes with greater than two-fold expression changes are reported here. Ambient conditions were $28^{\circ} \mathrm{C}, 100 \%$ air saturation, and 36 ppt salinity.

Click here for file

[http://www.biomedcentral.com/content/supplementary/14712164-8-358-S1.pdf]

\section{Additional file 2}

Changes in mRNA expression levels in heat-stressed Pomacentrus moluccensis, exposed to elevated temperatures $\left(31^{\circ} \mathrm{C}\right)$ for five days compared to $\mathrm{P}$. moluccensis kept at ambient temperature $\left(28^{\circ} \mathrm{C}\right)$ for five days. Only genes for which information regarding gene function is currently available are reported here. Where multiple functions have been identified for a gene, the gene function most relevant in the context of this study is reported. GenBank accession numbers refer to the Danio rerio clones represented on the microarray. Genes were ranked according to statistical significance as determined by Bayesian analysis of the expression response across biological replicates. Negative values of fold change indicate down-regulation of a gene in heat-stressed $\mathrm{P}$. moluccensis, while positive values indicate up-regulation ( $p$-values are FDR-corrected). Click here for file

[http://www.biomedcentral.com/content/supplementary/14712164-8-358-S2.pdf]

\section{Acknowledgements}

This research was supported by grants from the Hermon Slade Foundation (MJC), Estate of Winifred Violet Scott (RHC, MJC), Australian Research Council (RHC, MJC, ACW), a Merit Research Grant from James Cook University (RHC), and the School of Marine and Tropical Biology, James Cook University (RHC, KSK). This work conforms to ethical requirements at relevant authorities and collection of animals was authorised from the Great Barrier Reef Marine Park Authority, permit number G04/I233I.I. We thank the Lizard Island Research Station for providing facilities and assistance during field experiments, and Dr. Ashley Connolly at the Adelaide Microarray Facility for providing facilities and assistance for the microarray experiments. We also thank Ching Crozier for technical guidance with the laboratory work, Lewis Anderson for assistance with the collection of fish and performance of stress experiments, and A/Prof Andrew Perkins, Milena Gongora, and Simon Wilkins at the Institute for Molecular Bioscience, University of Queensland, for assistance with the annotation of the zebrafish microarray features. 


\section{References}

I. Farrell AR: Cardiorespiratory performance in salmonids during exercise at high temperature: insights into cardiovascular design limitations in fishes. Comp Biochem Physiol Part A Mol Integr Physiol 2002, I32(4):797-8I0.

2. Pörtner HO: Climate variations and the physiological basis of temperature dependent biogeography: systemic to molecular hierarchy of thermal tolerance in animals. Comp Biochem Physiol Part A Mol Integr Physiol 2002, I32(4):739-76I.

3. St-Pierre J, Charest PM, Guderley $\mathrm{H}$ : Relative contribution of quantitative and qualitative changes in mitochondria to metabolic compensation during seasonal acclimatisation of rainbow trout Oncorhynchus mykiss. J Exp Biol 1998, 20I(2I):296I-2970.

4. Lannig G, Bock C, Sartoris FJ, Pörtner HO: Oxygen limitation of thermal tolerance in cod, Gadus morhua L., studied by magnetic resonance imaging and on-line venous oxygen monitoring. Am J Physiol Reg Integ Comp Physiol 2004, 287(4):R902-R9I0.

5. Mark FC, Bock C, Pörtner HO: Oxygen-limited thermal tolerance in Antarctic fish investigated by MRI and P-3 I-MRS. Am J Physiol Reg Integ Comp Physiol 2002, 283(5):R I 254-R I 262.

6. Heise K, Puntarulo S, Nikinmaa M, Abele D, Pörtner HO: Oxidative stress during stressful heat exposure and recovery in the North Sea eelpout Zoarces viviparus L. J Exp Biol 2006, 209(2):353-363.

7. Abele D, Puntarulo S: Formation of reactive species and induction of antioxidant defence systems in polar and temperate marine invertebrates and fish. Comp Biochem Physiol Part A Mol Integr Physiol 2004, I 38(4):405-4I5.

8. Parihar MS, Javeri T, Hemnani T, Dubey AK, Prakash P: Responses of superoxide dismutase, glutathione peroxidase and reduced glutathione antioxidant defenses in gills of the freshwater catfish (Heteropneustes fossilis) to short-term elevated temperature. J Therm Biol 1997, 22(2): I5I-I56.

9. Dietz TJ: Acclimation of the threshold induction tempera-

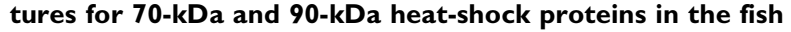
Gillichthys mirabilis. J Exp Biol 1994, 188:333-338.

10. Airaksinen S, Rabergh CMI, Lahti A, Kaatrasalo A, Sistonen L, Nikinmaa $M$ : Stressor-dependent regulation of the heat shock response in zebrafish, Danio rerio. Comp Biochem Physiol Part A Mol Integr Physiol 2003, I 34(4):839-846.

II. Airaksinen S, Rabergh CMI, Sistonen L, Nikinmaa M: Effects of heat shock and hypoxia on protein synthesis in rainbow trout (Oncorhynchus mykiss) cells. J Exp Biol 1998, 20I( I 7):2543-255I.

12. Iwama GK, Thomas PT, Forsyth RHB, Vijayan MM: Heat shock protein expression in fish. Rev Fish Biol Fish 1998, 8(1):35-56.

13. Gracey AY, Fraser EJ, Li W, Fang Y, Taylor RR, Rogers J, Brass A, Cossins AR: Coping with cold: An integrative, multitissue analysis of the transcriptome of a poikilothermic vertebrate. Proc Natl Acad Sci U S A 2004, I 0 I(48): I6970-I6975.

14. Ju Z, Dunham RA, Liu Z: Differential gene expression in the brain of channel catfish (Ictalurus punctatus) in response to cold acclimation. Mol Genet Gen 2002, 268(I):87-95.

15. Podrabsky JE, Somero GN: Changes in gene expression associated with acclimation to constant temperatures and fluctuating daily temperatures in an annual killifish Austrofundulus limnaeus. J Exp Biol 2004, 207(1 3):2237-2254.

16. Cossins A, Fraser J, Hughes M, Gracey A: Post-genomic approaches to understanding the mechanisms of environmentally induced phenotypic plasticity. J Exp Biol 2006, 209(1 2):2328-2336.

17. Cohen DM: Mitogen-activated protein kinase cascades and the signaling of hyperosmotic stress to immediate early genes. Comp Biochem Physiol A Comp Physiol 1997, I I 7(3):29I-299.

18. Cowan KJ, Storey KB: Mitogen-activated protein kinases: new signaling pathways functioning in cellular responses to environmental stress. J Exp Biol 2003, 206(7): I I07-III 5.

19. Gabai VL, Sherman MY: Interplay between molecular chaperones and signaling pathways in survival of heat shock. J Appl Physiol 2002, 92(4): 1743-I748.

20. Gius D, Mattson D, Bradbury CM, Smart DK, Spitz DR: Thermal stress and the disruption of redox-sensitive signalling and transcription factor activation: possible role in radiosensitization. Int J Hyperth 2004, 20(2):21 3-223.
21. Morgan Jl, Curran T: Immediate-early genes: ten years on. Trends Neurosci 1995, 18(2):66-67.

22. Hofmann GE, Buckley BA, Airaksinen S, Keen JE, Somero GN: Heatshock protein expression is absent in the Antarctic fish Trematomus bernacchii (family Nototheniidae). J Exp Biol 2000, 203(I 5):2331-2339.

23. Kassahn KS, Caley MJ, Ward AC, Connolly AR, Stone G, Crozier R: Heterologous microarray experiments used to identify the early gene response to heat stress in a coral reef fish. Mol Ecol 2007, 16:1749-1763.

24. Barrett T, Suzek TO, Troup DB, Wilhite SE, Ngau WC, Ledoux P, Rudnev D, Lash AE, Fujibuchi W, Edgar R: NCBI GEO: mining millions of expression profiles - database and tools. Nucl Acids Res 2005, 33(suppl_I):D562-566.

25. Massague J: GI cell-cycle control and cancer. Nature 2004, 432(70 I 5):298-306.

26. Carmeliet P, Dor Y, Herbert JM, Fukumura D, Brusselmans K, Dewerchin M, Neeman M, Bono F, Abramovitch R, Maxwell P, Koch CJ, Ratcliffe P, Moons L, Jain RK, Collen D, Keshert E: Role of HIF-I alpha in hypoxia-mediated apoptosis, cell proliferation and tumour angiogenesis. Nature 1998, 394(6692):485-490.

27. Pedersen SF, Hoffmann EK, Mills JW: The cytoskeleton and cell volume regulation. Comp Biochem Physiol Part A Mol Integr Physiol 200I, I30(3):385-399.

28. Hall A: Rho GTPases and the control of cell behaviour. Biochem Soc Trans 2005, 33:891-895.

29. Hofmann GE, Somero GN: Interspecific variation in thermal denaturation of proteins in the congeneric mussels Mytilus trossulus and $M$. galloprovincialis: Evidence from the heat shock response and protein ubiquitination. Mar Biol 1996, I 26(I):65-75.

30. Hofmann GE, Somero GN: Evidence for protein damage at environmental temperatures - seasonal changes in levels of ubiquitin conjugates and Hsp70 in the intertidal mussel Mytilus trossulus. J Exp Biol 1995, I98(7): |509-1518.

31. Houlihan DF: Protein turnover in ectotherms and its relationships to energetics. Adv Comp Environ Physiol 1991, 7:1-43.

32. Gasch AP, Spellman PT, Kao CM, Carmel-Harel O, Eisen MB, Storz $G$, Botstein D, Brown PO: Genomic expression programs in the response of yeast cells to environmental changes. Mol Biol Cell 2000, I I ( I 2):424 I-4257.

33. Aoshiba K, Yasuda K, Yasui S, Tamaoki J, Nagai A: Serine proteases increase oxidative stress in lung cells. Am J Physiol - Lung, Cell \& Mol Physiol 200I, 28 I (3):L556-L564.

34. Lupes SC, Davis MW, Olla BL, Schreck CB: Capture-related stressors impair immune system function in sableflsh. Trans Am Fish Soc 2006, I35(1): 129-138.

35. Bly JE, Clem LW: Temperature-mediated processes in teleost immunity - in vitro immunosuppression induced by in vivo low temperature in channel catfish. Vet Immunol Immunopathol |99|, 28(3-4):365-377.

36. Fischman HK, Pero RW, Kelly DD: Psychogenic stress induces chromosomal and DNA damage. Int J Neurosc 1996, 84(14):219-227.

37. Kültz D: Molecular and evolutionary basis of the cellular stress response. Annu Rev Physiol 2005, 67:225-257.

38. Kikuchi K, Yamashita M, Watabe S, Aida K: The warm-temperature-acclimation-related 65-kDa protein, Wap65, in goldfish and its gene expression. J Biol Chem 1995, 270(29): I 7087-I7092.

39. Picard DJ, Schulte PM: Variation in gene expression in response to stress in two populations of Fundulus heteroclitus. Comp Biochem Physiol Part A Mol Integr Physiol 2004, I37(I):205-2I6.

40. Sarmiento J, Leal S, Quezada C, Kausel G, Figueroa J, Vera MI, Krauskopf M: Environmental acclimatization of the carp modulates the transcription of beta-actin. J Cell Biochem 2000, 80(2):223-228.

41. Vera MI, Ríos HM, de la Fuente E, Figueroa J, Krauskopf M: Seasonal acclimatization of the carp involves differential expression of 5.8S ribosomal RNA in pituitary cells. Comp Biochem Physiol Part B Biochem Mol Biol 1997, I I 8(4):777-78I.

42. Semenza GL, Roth PH, Fang HM, Wang GL: Transcriptional regulation of genes encoding glycolytic enzymes by hypoxiainducible factor-I. J Biol Chem 1994, 269(38):23757-23763.

43. Schmedtje JF, Ji YS: Hypoxia and molecular cardiovascular medicine. Trends Cardiovasc Med I998, 8(I):24-33. 
44. Semenza GL: HIF-I: mediator of physiological and pathophysiological responses to hypoxia. J Appl Physiol 2000, 88(4): | 474- |480.

45. Semenza GL: Hypoxia-inducible factor I: master regulator of O2 homeostasis. Curr Opin Genet Dev 1998, 8(5):588-594.

46. Semenza GL: Regulation of physiological responses to continuous and intermittent hypoxia by hypoxia-inducible factor I. Exp Physiol 2006, 9 I (5):803-806.

47. Hirota K, Semenza GL: Regulation of angiogenesis by hypoxiainducible factor I. Crit Rev Oncol-Hematol 2006, 59(I):15-26.

48. Lesser MP: Oxidative stress in marine environments: Biochemistry and physiological ecology. Annu Rev Physiol 2006, 68:253-278.

49. Abele D, Heise K, Pörtner HO, Puntarulo S: Temperaturedependence of mitochondrial function and production of reactive oxygen species in the intertidal mud clam Mya arenaria. J Exp Biol 2002, 205(13): | $83|-| 84 \mid$.

50. Abele D, Burlando B, Viarengo A, Pörtner HO: Exposure to elevated temperatures and hydrogen peroxide elicits oxidative stress and antioxidant response in the Antarctic intertidal limpet Nacella concinna. Comp Biochem Physiol Part B Biochem Mol Biol 1998, I 20(2):425-435.

5I. Flanagan SW, Moseley PL, Buettner GR: Increased flux of free radicals in cells subjected to hyperthermia: detection by electron paramagnetic resonance spin trapping. FEBS Lett 1998, 43 I (2):285-286.

52. Rifkin JM, Abugo O, Levy A, Monticone R, Heim J: Formation of free radicals under hypoxia. In Surviving Hypoxia: Mechanisms of Control and Adaptation Edited by: Hochachka PW, Lutz PL, Sick T, Rosenthal M, van den Thillart G. Boca Raton, FL , CRC Press; 1993:509-525.

53. Freeman ML, Spitz DR, Meredith MJ: Does heat-shock enhance oxidative stress - studies with ferrous and ferric iron. Radiat Res 1990, I 24(3):288-293.

54. Heise K, Puntarulo S, Nikinmaa M, Lucassen M, Pörtner HO, Abele D: Oxidative stress and HIF-I DNA binding during stressful cold exposure and recovery in the North Sea eelpout (Zoarces viviparus). Comp Biochem Physiol Part A Mol Integr Physiol 2006, I 43(4):494-503.

55. Pörtner HO, Mark FC, Bock C: Oxygen limited thermal tolerance in fish? Answers obtained by nuclear magnetic resonance techniques. Resp Physiol Neurobiol 2004, I 4 I (3):243-260.

56. IPCC: Climate change 200I. IPCC Third Assessment Report. [http://www.ipcc.ch].

57. Hughes TP: Catastrophes, phase shifts, and large-scale degradation of a Caribbean coral reef. Science 1994, 265:| 547-I 550

58. Pandolfi JM, Bradbury RH, Sala E, Hughes TP, Bjorndal KA, Cooke RG, McArdle D, McClenachan L, Newman MJH, Paredes G, Warner RR, Jackson JBC: Global trajectories of the long-term decline of coral reef ecosystems. Science 2003, 30 I(5635):955-958.

59. Gardner TA, Cote IM, Gill JA, Grant A, Watkinson AR: Long-term region-wide declines in Caribbean corals. Science 2003, 301 (5635): $958-960$.

60. Hughes TP, Baird AH, Bellwood DR, Card M, Connolly SR, Folke C, Grosberg R, Hoegh-Guldberg O, Jackson JBC, Kleypas J, Lough JM, Marshall P, Nystrom M, Palumbi SR, Pandolfi JM, Rosen B, Roughgarden J: Climate change, human impacts, and the resilience of coral reefs. Science 2003, 30 I(5635):929-933.

61. Nilsson GE, Ostlund-Nilsson S: Hypoxia in paradise: widespread hypoxia tolerance in coral reef fishes. Proc $R$ Soc Lond B Biol Sci 2004, 27 I:S30-S33.

62. The Adelaide Microarray Facility: . [http://www.microarray.adelaide. edu.au].

63. Smyth GK: Limma: linear models for microarray data. In Bioinformatics and Computational Biology Solutions using $R$ and Bioconductor Edited by: Gentleman R, Carey V, Dudoit S, Irizarry R, Huber W. New York, Springer; 2005:397-420.

64. Smyth GK: Linear models and empirical Bayes methods for assessing differential expression in microarray experiments. Stat Appl Genet Mol Biol 2004, 3( I):Article 3.

65. Smyth GK, Speed TP: Normalization of cDNA microarray data. Methods 2003, 3 I:265-273.

66. Benjamini Y, Hochberg Y: Controlling the False Discovery Rate - a practical and powerful approach to multiple testing. J Roy Stat Soc Ser B Methodol 1995, 57(I):289-300.
67. Holm: A simple sequentially rejective multiple test procedure. Scand J Stat 1979, 6:65-70.

68. Tsai J, Sultana R, Lee Y, Pertea G, Karamycheva S, Antonescu V, Cho J, Parvizi B, Cheung F, Quackenbush F: RESOURCERER: a database for annotating and linking microarray resources within and across species. Genome Biol 200 I, 2(I I):software0002.I-2.4.

69. The Gene Ontology Consortium: Gene Ontology: tool for the unification of biology. Nat Genet 2000, 25:25-29.

70. Hoffmann $R$, Valencia A: A gene network for navigating the literature. Nat Genet 2004, 36:664.

7I. NCBI: . [http://www.ncbi.nlm.nih.gov/].

72. Lee HK, Braynen W, Keshav K, Pavlidis P: ErmineJ: Tool for functional analysis of gene expression data sets. BMC Bioinformatics 2005, 6:.

73. Eisen MB, Spellman PT, Brown PO, Botstein D: Cluster analysis and display of genome-wide expression patterns. Proceedings of the National Academy of Sciences of the United States of America 1998, 95(25): |4863-|4868.
Publish with Biomed Central and every scientist can read your work free of charge

"BioMed Central will be the most significant development for disseminating the results of biomedical research in our lifetime. "

Sir Paul Nurse, Cancer Research UK

Your research papers will be:

- available free of charge to the entire biomedical community

- peer reviewed and published immediately upon acceptance

- cited in PubMed and archived on PubMed Central

- yours - you keep the copyright
BiolMedcentral 